(4): All positive cerebrospinal fluid reactions at the end of a year are indicative that further treatment is necessary.

(5) The number of serological relapses was low : 2 in the malaria group and 3 in the malaria-plus-tryparsamide series.

(6) In no case tested after 2 consecutive negative results did the cerebrospinal fluid reactions revert to positive.

(7) In latent and asymptomatic neurosyphilis it is not necessary to supplement malaria therapy with chemotherapy.

(8) Penicillin may well replace tryparsamide as an accessory to malaria therapy.

\title{
REFERENCES
}

Blalock, J. R., and Hinsie, L. E. (1938) Psych. Quart., 12, 84.

Dattner, B., Thomas, E. W., and Wexler, Gertrude (1944) ${ }^{1}$ The Management of Neurosyphilis. Grune \& Stratton, New York ; Wm. Heinemann, London.

- - (1944) ${ }^{2}$ Amer. J. Syph., 28, 265.

Downs, W. G., McDermott, W., and Webster, B. (1941) Amer. J. Syph., 25, 16.

Gammon, G. D., Stokes, J. H., Beerman, H., Ingraham, N. R. Jun., Lentz., J. W., Morgan, H. G., Steele, W., and Rose, Elizabeth K. (1945) J. Amer. med. Ass., 128, 653. Goldman, D. (1945) J. Amer. med. Ass., 128, 274.

Hinrichsen, Josephine (1939) J. vener. Dis. Inform., 20, 293.

Kopp, I., and Solomon, H. C. (1940) Amer. J. Syph., 24, 265.

Marsh, J. D. (1944) M. Bull. Vet. Admin., 21, 171.

Neymann, C. A., Heilbrunn, G., and Youmans, G. P. (1945) J. Amer. med. Ass., 128, 433.

Nicol, W. D., and Hutton, E. L. (1937) Brit. J. vener. Dis., 13, 141.

O'Leary, P. A. (1937) J. Amer. med. Ass., 109, 1163.

- Breutsch, W. L., Ebaugh, F. G., Simpson, W. M., Solomon, H. C., Warren, S. L., Vonderlehr, R. A., Usilton, Lida J., and Sollins, I. V. (1940) J. vener. Dis. Inform., 21, 278.

- Brunsting, L. A., and Ockerly, O. (1946) J. Amer. med. Ass., 130, 698.

Rose, A. S., Trevett, L. D., Hindle, J. A., Prout, C., and Solomon, H. C. (1945) Amer. J. Syph., 29, 487.

Solomon, H. C., and Epstein, S. H. (1935) Arch. Neurol. Psychiat., 33, 1008.

Stokes, J. H., Mahoney, J. F., Moore, J. E., and Wood, W. B. (1944) J. Amer. med. Ass., 126, 73.

Thomas, E. W. (1945) Amer. J. Syph., 29, 667.

\section{CHANGES IN THE CEREBROSPINAL FLUID IN NEUROSYPHILIS AFTER MALARIA THERAPY*}

\author{
By MAEVE WHELEN, M.D., D.P.M. \\ From the Malaria Therapy Centre, Horton Emergency Hospital, Epsom, Surrey
}

The results of malaria therapy in the treatment of neurosyphilis are assessable from two aspects, clinical and serological. From the point of view of the patient, of his relatives and of the community, the former is obviously the more useful and for a long time it was, and sometimes it still is, the only thing considered. This outlook was inevitable until some sort of working hypothesis could be produced to explain the action of malaria.

It is now more or less generally accepted that malaria is a spirochaeticidal agent and that its success in neurosyphilis is due to its action in bringing about the death of the spirochaetes. In order to assess the success or failure of the treatment we need some indicator of the presence of the living organism. This has been found in the cerebrospinal fluid. A positive reaction of the cerebrospinal fluid indicates the presence of living spirochaetes, a negative one of dead organisms. We have here a simple and straightforward means of telling how successful the treatment has been.

\footnotetext{
* An address to the Medical Society for the Study of Venereal Diseases, 27th April, 1946.
} 


\section{THE BRITISH JOURNAL' OF VENEREAL DISEASES}

The difficulty which is encountered in the general acceptance of the cerebrospinal fluid as the main gauge is that at times the clinical and serological results appear to be at variance. This is due to the fact that the clinical result depends not only upon the death of the causative organism and the subsidence of the inflammatory reaction, but also upon the degree of destruction of nerve tissue that has occurred. It is the failure to recognize this latter factor that has led to the conflicting reports as to the efficiency or otherwise of malaria therapy.

With a view to underlining the fundamental importance of the cerebrospinal fluid, it was decided, in presenting our results, to ignore the clinical aspect and to concentrate on the changes found in the cerebrospinal fluid after malaria therapy.

In order that the cerebrospinal fluid may be investigated to the best advantage, it is essential that the examination be complete. The report should contain the following four things, namely:

(1) a cell count;

(2) a total protein estimation ;

(3) a Lange colloidal gold test curve ;

(4) a Wassermann reaction.

They have been put in this order because it is considered to be the order of precedence. This point is enlarged upon below.

A factor which is sometimes overlooked is the time interval between the last cerebrospinal fluid examination and the commencement of treatment. This is especially important if any other form of treatment has been given previously. The importance of this factor has just been impressed upon us again by the following case.

Application was made recently to the Malaria Therapy Centre for the admission of a woman suffering from general paralysis of the insane. The patient was duly admitted and she brought with her a note from the hospital which had applied for her admission, saying she had been treated there about 6 months previously with penicillin and that the reaction of the cerebrospinal fluid examined immediately after treatment was positive. It added that another lumbar puncture had been done the previous day and that they would let us know the result as soon as it came to hand. They did so and reported that the reaction of the fluid was negative.

It is proposed, therefore, to examine the changes seen in the individual items of the cerebrospinal fluid and in the fluid as a whole, and to discuss their significance as guides to the adequacy or inadequacy of the treatment.

\section{The cell count}

The cell count is probably the most important item in the examination of the cerebrospinal fluid. First, an increase in the number of cells (taking 5 or less per cubic millimetre as being within the normal range) is now generally accepted as indicative of an active or potentially active disease process. It is necessary to add the latter statement, since a case of latent or asymptomatic neurosyphilis, in which the disease is apparently quiescent, usually exhibits a count higher than normal. Secondly, the cell count is the most reliable index of the course of the disease. In almost every malaria-treated case it is the first to revert to normal, and the reversion is usually rapid and permanent.

An investigation of 525 of our patients in whom the cerebrospinal fluid had been examined within from 6 months to a year after treatment with malaria, of whom 352 were men and 173 women, gave the following results: in the men in 298 cases ( 85 per cent) the cell count was normal within the year and in 54 cases (15 per cent) it remained high. The percentages for the women were almost identical. The two sub-groups were then analysed with regard to the ultimate state of the cerebrospinal fluid as a whole.

In the case of the group in which the cell count fell to normal within the year, it was found that in the men in 23 cases ( 8 per cent) the fluid reverted and the reaction became strongly positive, in 15 (5 per cent) it reverted to a weak positive, in 87 ( 29 per cent) it remained inactive and in 173 (58 per cent) it became negative. (For a description of these four types of cerebrospinal fluid see page 124.) 


\section{CHANGES IN CEREBROSPINAL FLUID IN NEUROSYPHILIS}

In the patients in whom the raised cell count was relatively persistent, it was found that 29 (53 per cent) maintained their high count, 1 ( 2 per cent) improved to the extent of having a weakly positive fluid ; in 9 (17 per cent) an inactive fluid developed and in 15 (28 per cent) the reaction finally became negative.

The results in women were slightly more consistent ; of those whose cell count fell to normal, numbering 149 , only $2(1.4$ per cent) relapsed, the fluid becoming strongly positive, and in $100(67 \cdot 1$ per cent) it eventually became negative ; of the 24 with a relatively persistent increase in cells, 19 (79 per cent) showed a persistently strongly positive reaction and only in 3 (12.6 per cent) did it become negative. (See Tables 1 and 2.)

TABLE 1-CELL COUNT ONE YEAR AFTER MALARIAL TREATMENT

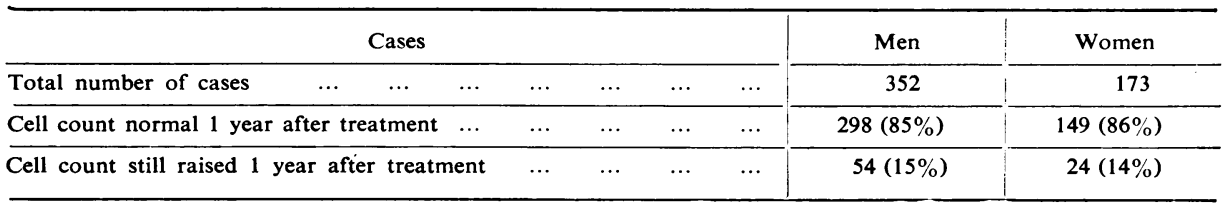

A further analysis of the cases in Table 1 may be made, as shown in Table 2. TABLE 2-COMPARISON OF CELL COUNT AND OF CEREBROSPINAL FLUID AS A WHOLE IN CASES ANALYSED IN TABLE 1

\begin{tabular}{|c|c|c|c|c|}
\hline \multirow[b]{2}{*}{ Cases } & \multicolumn{2}{|c|}{$\begin{array}{l}\text { Cell count normal } 1 \text { year } \\
\text { after treatment }\end{array}$} & \multicolumn{2}{|c|}{$\begin{array}{l}\text { Cell count still raised } 1 \text { year } \\
\text { after treatment }\end{array}$} \\
\hline & Men & Women & Men & Women \\
\hline Total number & 298 & 149 & 54 & 24 \\
\hline $\begin{array}{l}\text { Number in which cerebrospinal fluid became } \\
\text { strongly positive } \ldots \\
\end{array}$ & $23(8 \%)$ & $2(1 \cdot 4 \%)$ & $29(53 \%)$ & $19(79 \%)$ \\
\hline $\begin{array}{l}\text { Number in which cerebrospinal fluid became } \\
\text { weakly positive } \quad \ldots \\
\end{array}$ & $15(5 \%)$ & $9(6 \%)$ & $1(2 \%)$ & $2(8 \cdot 4 \%)$ \\
\hline $\begin{array}{l}\text { Number in which cerebrospinal fluid became } \\
\text { inactive } \\
\text { Nuc }\end{array}$ & $87(29 \%)$ & $38(25 \cdot 5 \%)$ & $9(17 \%)$ & - \\
\hline $\begin{array}{l}\text { Number in which cerebrospinal fluid became } \\
\text { negative } \\
\text { ne }\end{array}$ & $173(58 \%)$ & $100(67 \cdot 1 \%)$ & $15(28 \%)$ & $3(12 \cdot 6 \%)$ \\
\hline
\end{tabular}

For explanation of classification used, see p. 124

The most remarkable thing in these figures is the big difference between the number of cases in which the cell count falls to normal within a year $(85$ per cent in the men and 86 per cent in the women) and those in which the count remains high (15 per cent and 14 per cent respectively). The next most obvious finding is the relatively small percentage of cases (men 8 and women 1.4) in which the patient with a normal cell count relapses. Finally, in most cases in which the cell count remains high for more than a year there is only about a fifty-fifty chance or less that the cerebrospinal fluid will eventually become normal.

To summarize the results :

(1) in the majority of cases the cell count is within normal limits within a year from treatment;

(2) if the cell count becomes normal, it is very unlikely that it will revert, and there is a fair possibility that the reactions of the fluid will eventually become negative ;

(3) if the cell count is still increased a year after treatment, it is highly probable that it will remain so unless further treatment is given.

\section{The total protein estimation}

Malaria has very much the same effect on the amount of protein present in the cerebrospinal fluid as on the cell count. There is usually a marked and rapid reduction, which is relatively permanent. If the estimation is recorded in grammes 
or milligrams per cent a certain amount of fluctuation may be seen, and in some cases the total may remain moderately high even when the reactions to all other tests are normal.

In 458 of our patients, of whom 299 were men and 159 women, in whose cases the total protein was recorded in grammes or milligrams per cent, it was found that within a year from the end of treatment 83 per cent showed a marked reduction and 17 per cent either no reduction or even an increase. These percentages were identical for both men and women. It will be seen that the figures are very similar to the comparable ones for the cell count. (See Table 3.)

TABLE 3-TOTAL PROTEIN ONE YEAR AFTER TREATMENT

\begin{tabular}{|c|c|c|c|c|c|c|c|}
\hline \multirow[b]{2}{*}{ Total number of cases } & \multicolumn{2}{|r|}{ Cases } & \multicolumn{3}{|c|}{. } & \multirow{2}{*}{$\begin{array}{l}\text { Men } \\
299\end{array}$} & \multirow{2}{*}{$\frac{\text { Women }}{159}$} \\
\hline & $\ldots$ & $\ldots$ & $\ldots$ & $\ldots$ & $\ldots$ & & \\
\hline \multicolumn{6}{|c|}{ Number showing reduction of total protein 1 year after treatment $\quad \ldots$} & $248(83 \%)$ & $132(83 \%)$ \\
\hline \multicolumn{6}{|c|}{ Number showing no reduction of total protein 1 year after treatment ... } & $51(17 \%)$ & $27 .(17 \%)$ \\
\hline
\end{tabular}

\section{The Wassermann reaction and the Lange curve}

It is not proposed to say much about these except that in time they both usually become normal. They are not so important, as isolated items, as is either the cell count or even the protein content ; their main significance appears in considering the cerebrospinal fluid as a whole.

TABLE 4-FINAL CONDITION OF THE CEREBROSPINAL FLUID

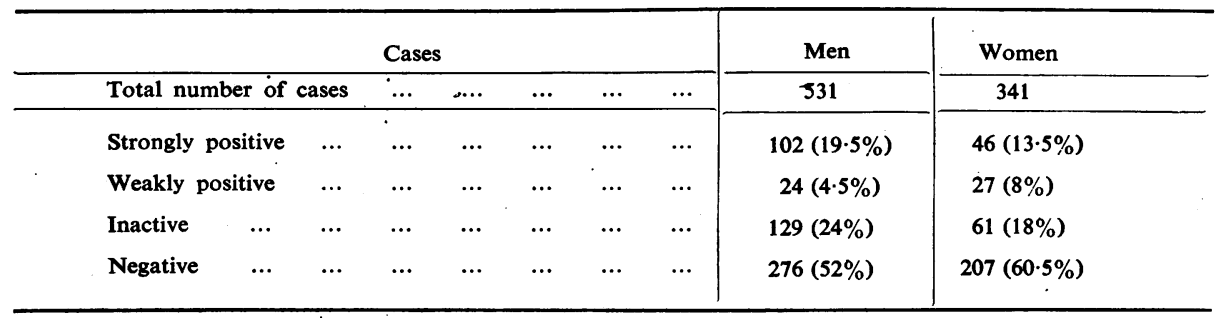

\section{The cerebrospinal fluid as a whole}

It cannot be too strongly emphasized that, in assessing the results of treatment, it is the state of the cerebrospinal fluid as a whole which must be considered. To facilitate the handling of the material Dattner's classification had been adopted (Dattner, Thomas and Wexler), namely :
(1) strongly positive ;
(2) weakly positive ;
(3) inactive ;
(4) negative.

A strongly positive fluid is characterized by having a strongly positive Wassermann reaction, that is $(+30$ or $+30+)$ a marked increase in the cell count and total protein estimation and a paretic Lange (colloidal gold test) curve. In a weakly positive fluid the Wassermann may vary from a strongly positive to a positive reaction (from +30 to +15 ), the cell count may be within normal limits or slightly raised, the total protein estimation is increased and the Lange curve is paretic. An inactive fluid is one in which the Wassermann reaction is positive, the cell count is normal, there is a marked reduction in the total protein and the Lange curve may or may not be paretic. A negative fluid shows a negative Wassermann reaction, a normal cell count, a relatively low total protein estimation (40 milligrams per cent or under), and a normal Lange curve. These four groups merge so imperceptibly into each other that it is impossible to lay down any hard and fast rule as to where one ends and another begins. 
In order to obtain a general picture of what happens to the cerebrospinal fluid after malaria therapy an analysis was made of the results in 872 of our patients, of whom 531 were men and 341 women. In 102 men (19.5 per cent) the fluid remained strongly positive, in 24 (4.5 per cent) it was weakly positive, in 129 (24 per cent) it was inactive and in 276 (52 per cent) it was negative. The apparently better results in the women probably can be explained by the fact that many of the patients included in the series have been followed up over a longer period than have the men. In 46 cases (13.5 per cent) the cerebrospinal fluid remained strongly positive, in 27 cases ( 8 per cent) it became weakly positive, in 61 (18 per cent) inactive and in $207(60.5$ per cent) negative. (See Table 4.)

The question of the persistently positive fluids was then investigated to see whether or not it was possible to recognize them fairly soon after treatment. An analysis was made of all the patients, numbering 124 (men 97 and women 27), who had strongly positive cerebrospinal fluids a year after treatment. It was found that in the men $71(73.2$ per cent) remained strongly positive, 9 (9.3 per cent) became inactive and 17 (17.5 per cent) negative. The women gave very much the same picture, as can be seen in Table 5 .

TABLE 5-FINAL CONDITION OF THE CEREBROSPINAL FLUID STILL STRONGLY POSITIVE ONE YEAR AFTER TREATMENT

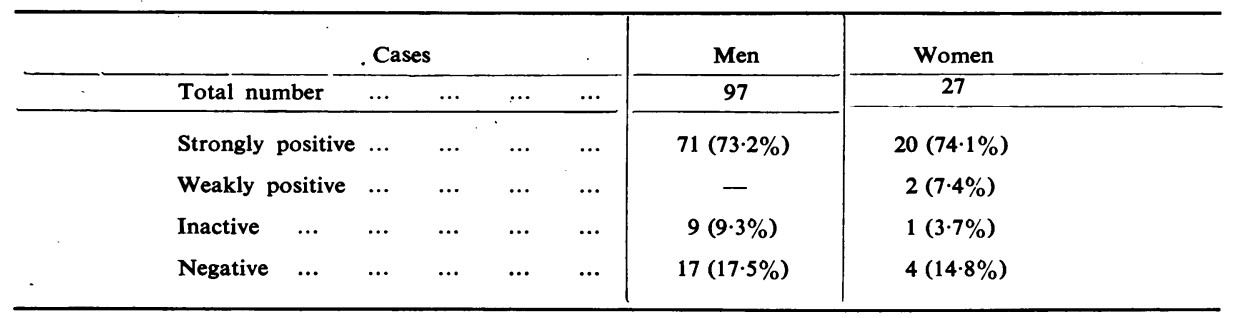

It must be borne in mind that this investigation is necessarily incomplete, and that it is probable that in some cases, if the cerebrospinal fluid had been examined over a longer period, the end result would have been different. The longest time between treatment and the last examination is 15 years and the shortest one year, the average being 2 years.

The following history is the clinical record of a patient showing a persistently positive cerebrospinal fluid.

Case 1.-J.K., male, aged 45 years, was admitted, 26.2.41, with a diagnosis of tabes and bilateral optic atrophy, the cerebrospinal fluid being strongly positive. He was infected with malaria and had 7 peaks of $103^{\circ} \mathrm{F}$. or over. He was discharged home, 14.7.41, and subsequently attended the follow-up clinic regularly. His general condition appeared to be satisfactory and there was no appreciable deterioration in his vision, but a year after treatment his cerebrospinal fluid was still decidedly positive.

Two years after his malarial treatment his wife reported that he was not so well. Two months previously he had lost the use of his legs for some hours and since then had seemed

" faintly off colour"'. Examination of his cerebrospinal fluid showed a persistently positive fluid. He was readmitted, 22.3.43, and given a further course of malaria. His general condition deteriorated so badly that the fever had to be stopped after only 4 peaks of $103^{\circ} \mathrm{F}$. or over. He was discharged home, 9.5.43. Although he had 4 additional peaks of fever only, these were apparently sufficient, since his last two tests have been negative. (See Chart 1.)

From the details in Chart 1 the conclusion might be drawn that, when the cerebrospinal fluid is strongly positive a year after malarial therapy, it will probably remain so unless further treatment is given.

The question of serological relapse is of interest, but apparently this occurs very rarely. Of 637 male patients only 17 (2.66 per cent) relapsed and of 437 female patients only $2(0.45$ per cent). When the time interval from the conclusion of treatment was considered, it was. found that 11 men (64.7 per cent) relapsed within 2 years, 2 (11.75 per cent) within 3 years and 4 (23.5 per cent) within 4 years. Both the relapses in women occurred within 2 years. (See Table 6.) 


\section{Negative cerebrospinal fluid}

The condition of the cerebrospinal fluid, like that of the blood, tends to fluctuate and presents the same problem as to whether or not a negative reaction will prove to be permanent. It is obviously undesirable to subject patients to periodical lumbar punctures for longer than is necessary. It would be extremely useful, therefore, if there were some criterion by which the permanence or otherwise of a negative result could be gauged.

CHART 1-SEROLOGICAL HISTORY OF CASE 1

\begin{tabular}{|c|c|c|c|c|c|c|c|}
\hline & \multirow{2}{*}{\multicolumn{3}{|c|}{ Findings }} & \multirow{2}{*}{$\begin{array}{c}\text { Before } \\
\text { treatment }\end{array}$} & \multicolumn{3}{|c|}{ After treatment } \\
\hline & & & & & 6 months & 1 year & 2 years \\
\hline W.R. & $\cdots$ & $\ldots$ & $\ldots$ & $+30+$ & $+30+$ & $+30+$ & $+30+$ \\
\hline Cells & $\cdots$ & $\ldots$ & $\ldots$ & Very numerous & 14 & 56 & 26 More malaria given \\
\hline Protein & $\ldots$ & $\ldots$ & $\ldots$ & 80 & 60 & $+\dot{+}$ & 70 \\
\hline Lange & $\cdots$ & $\ldots$ & $\ldots$ & 1223210000 & 1223211000 & 2211100000 & 5554321000 \\
\hline
\end{tabular}

RESULTS OBTAINED AT FOLLOW-UP EXAMINATIONS

\begin{tabular}{lll|c|c|c|c|c}
\hline \multicolumn{3}{c}{ Findings } & & $2 \frac{1}{2}$ years & 3 years & $3 \frac{1}{2}$ years & 4 years \\
\hline W.R. & $\ldots$ & $\ldots$ & $\ldots$ & +15 & +15 & +6 & +2 \\
Cells & $\ldots$ & $\ldots$ & $\ldots$ & 4 & 2 & - & - \\
Protein & $\ldots$ & $\ldots$ & $\ldots$ & 30 & 60 & 60 & 40 \\
Lange & $\ldots$ & $\ldots$ & $\ldots$ & 1232110000 & 3322110000 & 4433221000 & 2211000000 \\
\hline
\end{tabular}

W.R. = Wassermann reaction of cerebrospinal fluid. Lange $=$ Lange's colloidal gold test.

With this in mind, an investigation was made into 640 of our patients in whom there had been a negative cerebrospinal fluid at some time or other following malarial treatment. In this series there were 366 men and 274 women. The results in the men were as follows : in 7 ( 2 per cent) eventually the fluid reverted and became strongly positive again, in 3 ( 0.8 per cent) it reverted to a weak positive and in 14 (4 per cent) became inactive, whereas in $342(93.2$ per cent) it remained negative. The results in the women were similar. Both are shown in Table 7.

TABLE 6-SEROLOGICAL RELAPSES

\begin{tabular}{|c|c|c|c|c|c|c|c|c|}
\hline \multicolumn{7}{|c|}{ Cases } & \multirow{2}{*}{$\begin{array}{r}\text { Men } \\
637\end{array}$} & \multirow{2}{*}{$\begin{array}{c}\text { Women } \\
437\end{array}$} \\
\hline Total number of cases & $\cdots$ & $\ldots$ & .. & $\ldots$ & $\cdots$ & $\ldots$ & & \\
\hline Total number of relaps & & $\cdots$ & $\cdots$ & $\cdots$ & $\cdots$ & $\cdots$ & $17(2 \cdot 66 \%)$ & $2(0.45 \%)$ \\
\hline Number with relapse 2 & ars & ter $t$ & . & $\cdots$ & $\cdots$ & $\cdots$ & $11(64 \cdot 7 \%)$ & $2(100 \%)$ \\
\hline Number with relapse 3 & ars & ter & tme & $\cdots$ & $\because$ & $\cdots$ & $2(11 \cdot 75 \%)$ & 一 \\
\hline Number with relapse 4 & ars & ter & tme & $\cdots$ & $\cdots$ & $\because$ & $4(23 \cdot 5 \%)$ & - \\
\hline
\end{tabular}

The group, numbering 425 cases (men 246 and women 179), which had shown two or more consecutive negative results was next analysed. It was found that 99.6 per cent in the male and 100 per cent in the female cases remained consistently negative. (See Table 7.) The one male patient in whom it reverted to a weak positive is of particular interest. 


\section{CHANGES IN CEREBROSPINAL FLUID IN NEUROSYPHILIS}

Case 2.-A.P.K., male, age 41 years, was admitted, 15.7.41, with a diagnosis of general paralysis of the insane, the cerebrospinal fluid being strongly positive. He was infected with malaria and had 12 peaks of $103^{\circ} \mathrm{F}$. or over. He was discharged home, 29.9.41.

He attended the follow-up clinic regularly, and a year after treatment his cerebrospinal fluid was negative and remained so for another year. Thereafter his cerebrospinal fluid and mental and physical condition began to deteriorate very slowly but steadily. The deterioration, both serological and clinical, was so gradual that for some time it was almost unnoticed. Then one day he turned up "out of the blue", looking unkempt and miserable and in a state of considerable confusion. He was readmitted and a lumbar puncture was done. The cerebrospinal fluid, although not yet strongly positive, showed a marked deterioration. He was given a second course of malaria therapy, having 13 peaks of $103^{\circ} \mathrm{F}$. or over. The cerebrospinal fluid, examined 6 months later, although not then negative, was markedly improved. (See Chart 2.)

TABLE 7-NEGATIVE CEREBROSPINAL FLUIDS

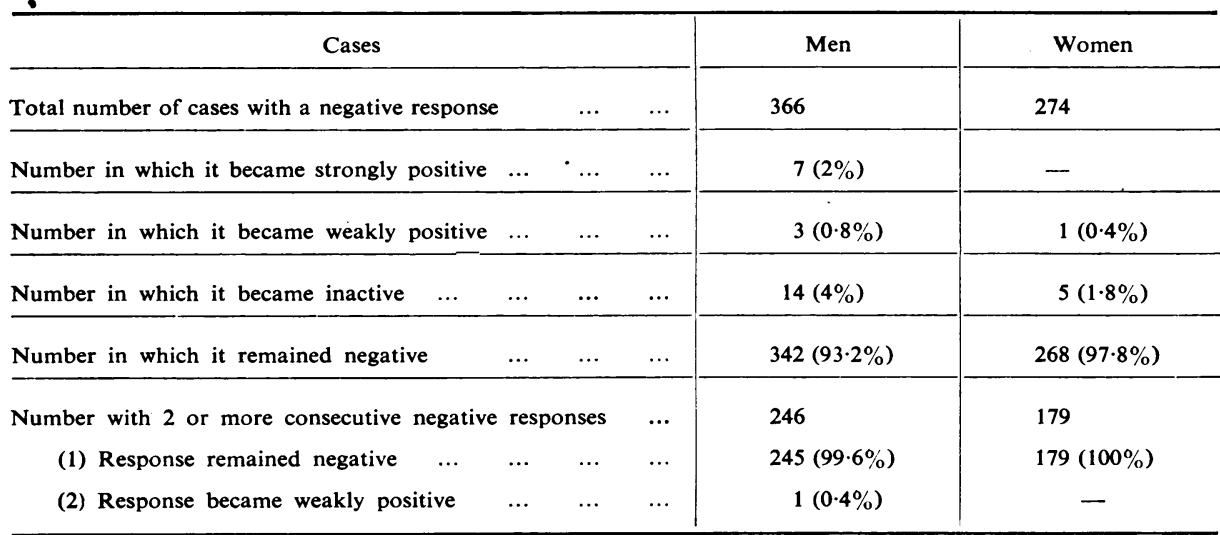

This case is of interest, not only. because of the serological relapse after three consecutive negative results, but also because of the extreme gradualness of the deterioration. As a general rule when a fluid reverts to positive it does so suddenly and dramatically.

CHART 2-SEROLOGICAL HISTORY OF CASE 2

\begin{tabular}{|c|c|c|c|c|c|c|c|}
\hline \multirow{2}{*}{\multicolumn{3}{|c|}{ Findings }} & \multirow{2}{*}{$\begin{array}{c}\text { Before } \\
\text { treatment }\end{array}$} & \multicolumn{4}{|c|}{ After treatment } \\
\hline & & & & 1 year & 18 months & 2 years & $2 \frac{1}{2}$ years \\
\hline W.R. & $\ldots$ & $\ldots$ & $+30+$ & $+6+$ & +2 & +2 & +6 \\
\hline Cells & $\ldots$ & $\ldots$ & 29 & - & 2 & - & 3 \\
\hline Protein & ... & $\ldots$ & 80 & 30 & 30 & - & 55 \\
\hline Lange & $\ldots$ & $\ldots$ & 5554432100 & - & 1232100000 & 1122100000 & 3332211000 \\
\hline
\end{tabular}

RESULTS OBTAINED IN FOLLOW-UP EXAMINATIONS

\begin{tabular}{lcc|c|c|c|c}
\hline \multicolumn{2}{c|}{ Findings } & 3 years & $3 \frac{1}{2}$ years & & 4 years \\
\hline W.R. & $\ldots$ & $\ldots$ & $+6+$ & $+30+$ & \\
Cells & $\ldots$ & $\ldots$ & 1 & 1 & \multicolumn{2}{c}{$\begin{array}{c}\text { Another course of } \\
\text { malaria given }\end{array}$} \\
Protein & $\ldots$ & $\ldots$ & 60 & 40 & & - \\
Lange & $\ldots$ & $\ldots$ & 4443211000 & 5554321000 & & 221100000 \\
\hline
\end{tabular}

W.R. = Wassermann reaction of cerebrospinal fluid.

Lange = Lange's collodial gold test. 


\section{THE BRITISH JOURNAL OF VENEREAL DISEASES}

The following case history is given to illustrate the importance of not being content with one isolated negative test, and to emphasize the necessity of doing serial lumbar punctures after treatment.

Case 3.-N.L., male, aged 30 years, was admitted, 19.2.41, with a diagnosis of early general paralysis, the cerebrospinal fluid being strongly positive. He was infected with malaria and had 10 peaks of $103^{\circ} \mathrm{F}$. or over. He was discharged home, 19.4.41.

After his discharge he attended the follow-up clinic regularly and seemed to be making good progress. He was well clinically and went back to his previous work, and the condition of his cerebrospinal fluid steadily improved until 18 months after treatment it was negative.

Six months later, that is, 2 years after the conclusion of treatment, the fluid suddenly reverted, becoming strongly positive, although there was no detectable clinical change. As this was a completely unexpected result, it was decided to check it before advising further malaria therapy, and the patient was asked to attend again in a month's time. He did so, and this second examination entirely confirmed the first. Clinically he was still apparently perfectly well.

On 7.5.43, he was readmitted and given a second course of malaria, having 6 peaks of $103^{\circ} \mathrm{F}$. or over. He was discharged home, 11.7.43.

Since his discharge he has continued to attend the follow-up clinic regularly. The condition of the cerebrospinal fluid has steadily improved, finally becoming negative 18 months after his second course of malaria. He has now had 3 consecutive negative tests, the last one being obtained 3 years after the conclusion of the second course of treatment. (See Chart 3.)

CHART 3-SEROLOGICAL HISTORY OF CASE 3

\begin{tabular}{|c|c|c|c|c|c|c|c|}
\hline \multirow{2}{*}{\multicolumn{3}{|c|}{ Findings }} & \multirow{2}{*}{$\begin{array}{c}\text { Before } \\
\text { treatment }\end{array}$} & \multicolumn{4}{|c|}{ After treatment } \\
\hline & & & & 6 months & 18 months & 2 years & \\
\hline W.R. & $\cdots$ & $\cdots$ & $+30+$ & +15 & +6 & $+30+$ & . \\
\hline Cells ... & $\cdots$ & $\cdots$ & Very numerous & 4 & 一 & 23 & Another course \\
\hline Protein & $\ldots$ & $\cdots$ & 160 & 50 & 40 & 100 & treatment given \\
\hline Lange & $\ldots$ & $\ldots$ & 5555443321 & 5554321000 & 2221000000 & 5555443100 & \\
\hline
\end{tabular}

RESULTS OBTAINED IN FOLLOW-UP EXAMINATIONS

\begin{tabular}{lcl|c|c|c|c|c|}
\hline \multicolumn{2}{c|}{ Findings } & $2 \frac{1}{2}$ years & 3 years & $3 \frac{1}{2}$ years & 4 years \\
\hline W.R. & $\ldots$ & $\ldots$ & +15 & +6 & $+2+$ & - \\
Cells $\ldots$ & $\ldots$ & $\ldots$ & 2 & 2 & 1 & - \\
Protein & $\ldots$ & $\ldots$ & 50 & 90 & 30 & 50 \\
Lange & $\ldots$ & $\ldots$ & 5554432100 & 4332210000 & 3322110000 & - \\
\hline
\end{tabular}

W.R. = Wassermann reaction of cerebrospinal fluid.

Lange $=$ Lange's colloidal gold test.

Next an attempt was made to find out something about the time which the cerebrospinal fluid takes to become negative. Investigation of 183 male cases in which the fluid had been examined at regular yearly intervals showed that within one year from the end of treatment 78 (42.6 per cent) and within three years $163(89 \cdot 1$ per cent) showed negative results. The results in the women were very similar ; out of 88 cases, 47 (53.4 per cent) and 82 (93.1 per cent) were negative within one year and 3 years respectively. (See Table 8.)

From the foregoing it seems to be justifiable to draw the following conclusions.

(1) It is not sufficient to be satisfied with one or even more than one isolated negative test result.

(z) When there have been at least two consecutive negative results it is safe to assume that a subsequent relapse is highly unlikely.

(3) The great majority of negative fluids become so within three years from the conclusion of treatment. 


\section{CHANGES IN CEREBROSPINAL FLUID IN NEUROSYPHILIS}

\section{Inactive cerebrospinal fluid}

If the cerebrospinal fluid is examined over a fair period of time, it will be noticed that in a certain percentage of cases the fluid becomes inactive and remains so. This raises the question of the significance of an inactive cerebrospinal fluid.

\section{TABLE 8-TIME, BETWEEN TREATMENT AND FIRST NEGATIVE RESPONSE}

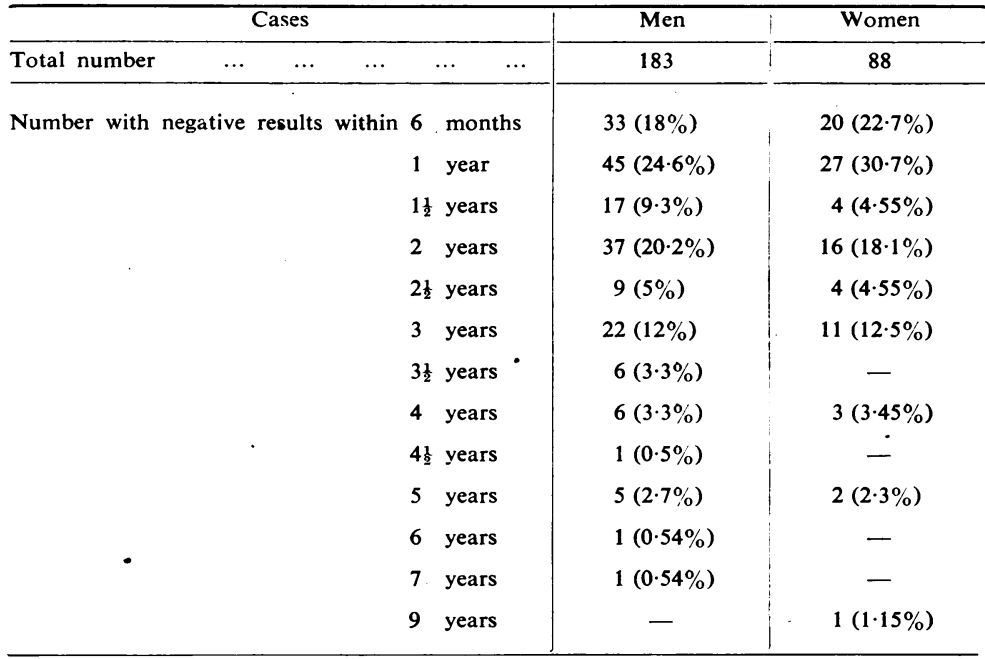

An investigation was made into 529 of our patients (men 347, women 182) from this standpoint. It was found that of the men 24 ( 7 per cent) eventually relapsed, the fluid becoming strongly positive, in 10 (2.9 per cent) it reverted to a weak positive, in 199 (57.3 per cent) it eventually became negative, and in $114(32.8$ per cent) it remained inactive. The analysis of the women gave fairly similar results.

TABLE 9-INACTIVE CEREBROSPINAL FLUIDS

\begin{tabular}{|c|c|c|}
\hline Cases & Men & Women \\
\hline Total number with an inactive response ... & 347 & 182 \\
\hline Number in which it became strongly positive ... & $24(7 \%)$ & $3(1 \cdot 6 \%)$ \\
\hline Number in which it became weakly positive $\ldots$ & $10(2 \cdot 9 \%)$ & $7(3.9 \%)$ \\
\hline Number in which it remained inactive ... & $114(32 \cdot 8 \%)$ & $73(40 \%)$ \\
\hline Number in which it became negative $\ldots$ & $199(57 \cdot 3 \%)$ & $99(54 \cdot 5 \%)$ \\
\hline $\begin{array}{c}\text { Number with } 2 \text { or more consecutive inactive } \\
\text { responses } \ldots \\
\cdots\end{array}$ & 185 & 84 \\
\hline (1) Remaining inactive or becoming negative... & $174(94 \%)$ & $79(94 \%)$ \\
\hline (2) Becoming weakly positive $\ldots \quad \ldots$ & $2(1 \cdot 1 \%)$ & $3(3 \cdot 6 \%)$ \\
\hline (3) Becoming strongly positive ... & $9(4.9 \%)$ & $2(2 \cdot 4 \%)$ \\
\hline
\end{tabular}

To bring this into line with the investigation of the negative cerebrospinal fluids, an analysis was made of 269 patients (men 185, women 84) in whom there had been two or more consecutive inactive results. It was found that the fluid reverted to positive in 11 men ( 6 per cent), in 9 (4.9 per cent) being strongly and in 
$2(1 \cdot 1$ per cent) weakly so ; in 174 (94 per cent) it remained inactive or became negative. As can be seen in Table 9, the results in the women were similar.

These results are like those obtained when dealing with the negative fluids. It is probable that a certain proportion of these so-called inactive specimens should have been classed with the negatives. There is no sharply defined line of demarcation between the two, which makes classification difficult. However, bearing this in mind, it seems to be justifiable to draw the following conclusions.

(1) An inactive fluid is unlikely to become positive again ;

(2) A persistently inactive fluid is not of serious import.

\section{Discussion}

Serial testing of the cerebrospinal fluid after treatment is of the greatest value. Nobody treating somatic syphilis nowadays would think of doing so without the help of repeated blood tests ; similarly, anybody dealing with neurosyphilis should be guided in his activity by the condition of the cerebrospinal fluid. It is not sufficient to wait until there is an obvious clinical relapse, since by that time irreparable damage may have been done. The cerebrospinal fluid is a much more delicate indicator than are the clinical $\cdot$ manifestations.

A point which may be raised here is this. What about those cases in which the disease continues to progress, or there is apparently relapse, in the presence of a negative fluid ? The answer is twofold. First, in the former case it has been suggested that if the damage to the nerve tissue is sufficiently severe and widespread it will continue, even in the absence of living spirochaetes. Secondly, in the latter case it is probable that the exacerbation of symptoms is due to some other process superimposed upon the arrested neurosyphilis. This is borne out by the histological examination, because in the absence of a positive fluid spirochaetes are not found nor is there evidence of active inflammatory changes in the brain. It is possible that in some cases the deterioration is the result of regressive changes due to ageing, which, in the presence of an already damaged brain, may tend to come on earlier and to produce more noticeable symptoms. In other cases the apparent relapse may be due to another psychosis, which may be more or less coloured by the arrested general paralysis, making the diagnosis difficult.

The importance, both from the point of view of the patient and of research, of keeping a neurosyphilitic patient under prolonged supervision throws into relief the need for an efficient follow-up organization. It is only comparatively recently that the necessity of keeping patients under surveillance has been generally recognized, but it is not yet widely appreciated that this entails the provision of special facilities, if it is to be done to the best advantage. The first steps towards ensuring continued supervision can be taken whilst the patient is still undergoing treatment, but this by itself is not enough and the services of a suitable social worker and adequate clerical assistance are essential. These are not luxuries but necessities.

\section{Conclusions}

(1) The condition of the cerebrospinal fluid is the best indicator of the adequacy or inadequacy of treatment.

(2) For the cerebrospinal fluid to be used to the best advantage, the examination must be complete and should include :
(a) a cell count;
(b) a total protein estimation;
(c) a Lange colloidal gold test;
(d) a Wassermann test.

(3) After the conclusion of treatment, serial examinations of the cerebrospinal fluid should be made until at least two consecutive negative results have been obtained.

(4) The great majority of negative fluids become so within 3 years from the end of treatment. 
(5) The condition of the cerebrospinal fluid a year after treatment is a fairly reliable indicator of whether or not further treatment will be needed.

(6) The most important and reliable item in this connexion is the cell count. If it is normal, then probably all will be well ; if it is still raised it is a danger signal, and the giving of further treatment should be considered.

(7) The behaviour of the cerebrospinal fluid after malaria therapy is so comparatively regular that it is a wise precaution to check any unexpected findings.

(8) The serial testing of the cerebrospinal fluid implies keeping the patient under prolonged supervision. To implement this satisfactorily entails having an adequate follow-up organization.

(9) For the follow-up to be really satisfactory, the services of a suitable social worker and adequate clerical assistance are essential.

(10) A good follow-up helps not only the patient but also the doctor, because it enables him to assess his results more accurately.

\section{REFERENCE}

Dattner, B., Thomas, E.W., and Wexler, G. (1944) Amer. J. Syph. 28, 265.

\section{DISCUSSION ON THE PRECEDING PAPERS}

Dr. G. L. M. McElligott (the President) said that the lesson of the most interesting papers by Drs. Nicol and Whelen seemed to be "more lumbar punctures and yet more lumbar punctures". Those members who had been in the armed Forces during the past few years would all agree how very refreshing it was to be able to order patients into hospitals for investigation of the cerebrospinal fluid. Unfortunately, it was difficult to do this in civil practice, owing to the shortage of hospital beds. Members who had been in the armed Forces had discovered also how relatively common was asymptomatic neurosyphilis. Some of the patients were young men in their early twenties. He believed that in some of them the infection was possibly congenital. By the time that symptoms or signs developed the patients would probably be in the thirties and, because by that time risks of infection would probably be admitted, the true origin of the infection would be missed. In such cases positive cerebrospinal fluid reactions often reverted to negative with a minimum of treatment. When the patients were treated with trivalent arsenical compounds and bismuth their cerebrospinal fluid reactions were usually negative at the end of one course of treatment. Whether or not the cerebrospinal fluid reactions remained negative, he was unable to say; the recent war did not last long enough for these observations to be made. He understood that Dr. Nicol had suggested that if a patient had not relapsed after a year then he was pretty certain to be all right.

Dr. Nicol said that that was not correct. He had said that if a patient relapsed, sero-relapse might come on at any time, not necessarily within a year, but that all such cases would require further treatment. If at the end of a year a patient showed a strongly positive reaction he should be re-treated.

Dr. McElligott (continuing) said that the conclusion seemed to have been that if patients defaulted from treatment they were safe because their cerebrospinal fluid reactions were negative. Could one safely draw such a conclusion?

Dr. Nicol said that all patients should have the cerebrospinal fluid tested. He assumed that in those patients who had not been tested, but who were working well three or four years afterwards, the probability was that the reactions were negative.

Dr. T. E. Osmond wished to be the first to express his thanks to the authors for their admirable papers. Their results were so well documented that they might fairly be "taken as gospel". Dr. Whelen had pointed out that of 246 patients who had two consecutive negative findings in the cerebrospinal fluid only one had relapsed (presumably at the end of 6-12 months). In other words, the outlook for general paralysis of the insane was very much better than it was years ago ; it might almost be said to be good. He supposed that the series about which they had heard that afternoon was the best and most successful ever reported on in Great Britain or, probably, anywhere else. Speaking as a pathologist, he was naturally particularly interested in the cerebrospinal fluid examination, and he thought that a great advance had been made by the authors in showing that the cerebrospinal fluid test was the thing that mattered and that there was no need to worry about the clinical side. The result of the cerebrospinal fluid test was something by which one could be guided. If the reaction was negative one could say that the outlook was good. 